\title{
Poncet's disease diagnostic criteria decodes conundrum: Poncet's vs pseudo Poncet's
}

\author{
V. Shobha, A.M. Desai \\ Department of Clinical Immunology and Rheumatology, \\ St. John's National Academy of Health Sciences, Bengaluru, India
}

\section{SUMMARY}

Poncet's disease is very important and yet a challenging diagnosis of importance in countries with high TB endemicity (e.g. India). In this case series, we present 5 patients with diagnosed as Poncet's disease and in our tertiary health care center over 12 months and examine the performance of the diagnostic criteria suggested by Sharma and Pinto. The majority (4/5) of the patients were subsequently diagnosed and responded to anti-tuberculous therapy. In the other patient, a diagnosis of atypical seropositive rheumatoid arthritis or Pseudo Poncet's disease was established on follow up.

Key words: Poncet's disease; Tuberculosis; Anti tuberculosis treatment.

Reumatismo, 2019; 71 (1): 46-50

\section{INTRODUCTION}

Pon oncet's disease was first described and named after Antonin Poncet in 1897 as a polyarthritis associated with tuberculosis (TB). Poncet's disease is classified as a parainfectious $(1,2)$ rather than a reactive arthritis. It is defined as tuberculous rheumatism associated with visceral tuberculosis without direct bacteriological involvement of the joints (3). The pathogenesis is a Th1 cell-mediated immune response to a TB antigen. Molecular mimicry between mycobacterial heat shock protein (HSP65) and human HSP has been implicated in its causation (4). Over 100 cases have been reported in the literature (5). Despite government initiatives, as per the WHO 2015 statistics (6), India continues to have a high incidence of TB, with 2.2 million cases of TB for India out of a global incidence of 9.6 million.

A recent review notes that $35 \%$ of the total reported cases in the literature of Poncet's disease were from India (5). However, in clinical practice, Poncet's disease is considered as a rare diagnosis even in India, probably due to diagnostic difficulties and lack of awareness. It is also often difficult to establish a defini- tive temporal relationship between $\mathrm{TB}$ infection and the onset of inflammatory arthritis. In 2015, Sharma and Pinto (7) proposed simplified diagnostic criteria for Poncet's disease based on characteristics of 23 patients in their study. Novaes et al. (8) had previously also proposed comprehensive diagnostic criteria, which, however, are not frequently used in routine clinical practice.

\section{Aim}

To describe the clinical features and management of 5 suspected cases of Poncet's disease. To assess the clinical utility of the proposed 2015 Sharma and Pinto (7) diagnostic criteria of Poncet's disease in daily practice for appropriate treatment.

\section{MATERIALS AND METHODS}

\section{Study design}

A clinical description of 5 prospective patients with suspected Poncet's disease. Patients were followed up initially at 2-weekly intervals, then monthly to assess any progression of the disease and response to therapy. A comprehensive review of the English literature was performed in PubMed to support the discussion of the manu- 
Table I - The clinical features including investigation, management and diagnosis of the 5 patients with suspected Poncet's disease.

\begin{tabular}{|c|c|c|c|c|c|}
\hline Parameters & Case 1 & Case 2 & Case 3 & Case 4 & Case 5 \\
\hline Age (years) & 32 & 32 & 28 & 64 & 31 \\
\hline Sex & Female & Female & Male & Female & Female \\
\hline Vocation & Doctor & Doctor & Engineer & Home maker & $\begin{array}{l}\text { Clinical research } \\
\text { assistant }\end{array}$ \\
\hline Comorbidity & - & Hypothyroidism & - & DM, HTN & $\begin{array}{l}17 \text { weeks gestation } \\
\text { Depression }\end{array}$ \\
\hline $\mathrm{H} / \mathrm{O}$ TB & $\begin{array}{l}\text { Treated childhood } \\
\text { Pulmonary TB }\end{array}$ & - & - & - & - \\
\hline Joints involved & $\begin{array}{l}\text { B/L ankles, MTPs } \\
\text { Elbows, wrists }\end{array}$ & $\mathrm{B} / \mathrm{L}$ ankles & $\begin{array}{l}\text { B/L PIPs, wrists, } \\
\text { knees, ankles }\end{array}$ & B/L knees, ankles & $\begin{array}{l}\text { B/L knees, ankles, } \\
\text { PIPs, MCPs }\end{array}$ \\
\hline $\begin{array}{l}\text { Duration of } \\
\text { arthritis }\end{array}$ & 4 weeks & 2 weeks & 2 weeks & 3 weeks & 2 weeks \\
\hline Joint aspiration & Not done & Not done & Not done & Sterile synovial fluid & Not done \\
\hline Symptoms & - & $\begin{array}{l}\text { Fatigue, Body ache, } \\
\text { Pleuritic chest pain }\end{array}$ & $\begin{array}{l}\text { Pleuritic chest pain, } \\
\text { malaise }\end{array}$ & $\begin{array}{l}\text { Fever, weight loss, } \\
\text { fatigue }\end{array}$ & $\begin{array}{l}\text { PUO, weight loss, } \\
\text { Erythema Nodosum }\end{array}$ \\
\hline Chest $\mathrm{X}$ ray & Normal & Pleural effusion & Pleural effusion & $\begin{array}{l}\text { B/L upper lobe non } \\
\text { homogenous opacity }\end{array}$ & - \\
\hline TB diagnosis & $\begin{array}{l}\text { PET-CT scan: } \\
\text { Metabolically active } \\
\text { cervical, mediastinal } \\
\text { nodes s/o TB }\end{array}$ & Pleural Fluid analysis & Pleural Fluid analysis & Sputum AFB + & Clinical Diagnosis \\
\hline Treatment & $\begin{array}{l}\text { NSAIDs } \\
\text { Low dose steroids } \\
\text { ATT }\end{array}$ & $\begin{array}{l}\text { NSAIDs } \\
\text { ATT }\end{array}$ & $\begin{array}{l}\text { ATT } \\
\text { NSAIDs } \\
\text { Low dose steroid }\end{array}$ & $\begin{array}{l}\text { NSAIDs } \\
\text { Low dose steroids } \\
\text { ATT } \\
\text { DMARDs }\end{array}$ & $\begin{array}{l}\text { Low dose steroids } \\
\text { NSAIDs } \\
\text { ATT }\end{array}$ \\
\hline $\begin{array}{l}\text { Rheumatoid } \\
\text { Factor }\end{array}$ & Negative & Negative & Negative & Positive & Negative \\
\hline ANA & Negative & Negative & Negative & Negative & Negative \\
\hline $\begin{array}{l}\text { Final diagnosis } \\
\text { and outcome }\end{array}$ & $\begin{array}{l}\text { Poncet's disease, } \\
\text { Complete resolution }\end{array}$ & $\begin{array}{l}\text { Poncet's disease, } \\
\text { Complete resolution }\end{array}$ & $\begin{array}{l}\text { Poncet's disease, } \\
\text { Complete resolution }\end{array}$ & $\begin{array}{l}\text { Rheumatoid arthritis } \\
\text { (RF+) }\end{array}$ & $\begin{array}{l}\text { Poncet's disease, } \\
\text { Complete resolution }\end{array}$ \\
\hline
\end{tabular}

ATT, anti tubercular treatment; ANA, anti nuclear antibody; DM, diabetes mellitus; HTN, hypertension; NSAID, non steroidal anti inflammatory drugs; PET CT, positron emission tomography-computed tomography; RF, rheumatoid factor; TB, tuberculosis.

script. IERB approval (ethical approval) was obtained for this study.

\section{Inclusion criteria}

All patients with suspected Poncet's disease over 12 months were included in the study. All patients presented with either oligo or polyarthritis with features of active joint inflammation. The diagnosis of active TB was made on the basis of a high clinical index of suspicion and supportive investigations such as the Mantoux test, Chest radiograph, sputum examination for acid-fast bacilli (AFB), pleural fluid analysis and PET CT as indicated. After confirmation of active TB, all patients re- ceived NSAIDs with or without low dose steroids and standard antitubercular treatment (ATT).

\section{RESULTS}

The relevant clinical history, targeted investigations, treatment history and final diagnosis of the patients are presented in Tables I and II.

\section{DISCUSSION}

Our case series demonstrates that that the Sharma and Pinto diagnostic criteria performed very well in routine clinical practice, with good agreement in the majority 
Table II - The application for the diagnostic criteria for Poncet's disease as proposed by Sharma and Pinto (7).

\begin{tabular}{|c|c|c|c|c|c|c|}
\hline \multicolumn{2}{|c|}{ Sharma and Pinto diagnostic criteria ${ }^{7}$} & Case 1 & Case 2 & Case 3 & Case 4 & Case 5 \\
\hline \multirow{2}{*}{$\begin{array}{l}\text { Essential } \\
\text { criteria }\end{array}$} & Inflammatory, non-erosive, non-deforming arthritis & + & + & + & + & + \\
\hline & Exclusion of other causes of inflammatory arthritis & + & + & + & + & + \\
\hline \multirow{2}{*}{ Major criteria } & Concurrent diagnosis of extra-articular tuberculosis & + & + & + & + & + \\
\hline & Complete response to antitubercular therapy & + & + & + & - & + \\
\hline \multirow{3}{*}{ Minor criteria } & Mantoux positivity & + & - & - & - & - \\
\hline & $\begin{array}{l}\text { Associated hypersensitivity phenomenon, such as } \\
\text { erythema nodosum, tuberculids or phlyctenular } \\
\text { keratoconjunctivitis }\end{array}$ & + & - & - & - & + \\
\hline & Absence of sacroiliac and axial involvement & + & + & + & + & + \\
\hline \multirow{3}{*}{ Diagnosis } & Definite - Essential + two major & \multirow{3}{*}{$\begin{array}{l}\text { Definite } \\
\text { Poncet's } \\
\text { disease }\end{array}$} & \multirow{3}{*}{$\begin{array}{l}\text { Definite } \\
\text { Poncet's } \\
\text { disease }\end{array}$} & \multirow{3}{*}{$\begin{array}{l}\text { Definite } \\
\text { Poncet's } \\
\text { disease }\end{array}$} & \multirow{3}{*}{$\begin{array}{l}\text { Possible } \\
\text { Poncet's } \\
\text { disease }\end{array}$} & \multirow{3}{*}{$\begin{array}{l}\text { Definite } \\
\text { Poncet's } \\
\text { disease }\end{array}$} \\
\hline & Probable - Essential + one major + three minor & & & & & \\
\hline & $\begin{array}{l}\text { Possible - Essential + one major + two minor, } \\
\text { or Essential + three minor }\end{array}$ & & & & & \\
\hline
\end{tabular}

of the patients with suspected Poncet's disease. This has important implications in routine clinical practice, giving guidance to clinicians in making a rare diagnosis in relation to a common infection in endemic areas.

Poncet's disease was originally defined as polyarthritis associated with active TB infection. Joint involvement is essential to the diagnosis. In our case series all patients had evidence of arthritis: three patients with polyarthritis and 2 with oligoarthritis. In a recent review of 198 cases by Rueda et al. (5), multiple cases of oligoarthritis were reported. In our case series, the ankle joints were the most commonly involved. Similar observations have been reported by Sharma et al. (7). A possible useful clinical finding to help in the diagnosis of Poncet's disease is that none of our patients had monoarthritis, erosions or deformities at the time of diagnosis or during follow up. The duration of this disease has been reported to be highly variable, ranging between 3 days to 5 years (7). In our case series, the duration was comparatively much shorter.

As reflected by the diagnostic criteria, it is essential to exclude other possible forms of inflammatory arthritis. The common differential diagnoses include acute sarcoidosis or Lofgren's syndrome characterized by a triad of predominantly lower limb arthritis, erythema nodosum and bilateral hilar lym- phadenopathy. Other differential diagnoses include reactive arthritis and post infectious arthritis (viral arthritis). None of our patients had evidence of spondyloarthritis including axial involvement, the latter of which is one of the minor diagnostic criteria.

It is also equally important to distinguish the arthritis seen in Poncet's from an active tubercular infection of the joint. However, typical tubercular arthritis is destructive, erosive and predominantly presents as a monoarthritis, and with a predilection for the hip followed by the knee joint $(9,10)$. Also, unlike TB arthritis, Poncet's disease typically responds rapidly to standard ATT regimen. The response to ATT is a key feature observed in Poncet's disease as reflected through its inclusions as a major criterion.

Uncommon differential diagnoses include other inflammatory arthritides such as early rheumatoid arthritis. Case 4 presented with acute lower limb arthritis. Although her rheumatoid factor was positive it was difficult to make a definite diagnosis of rheumatoid arthritis (RA) at the time of initial presentation. Atypical features included typical manifestation of RA as a predominant small joint involvement of upper limbs, while the rheumatoid factor is often positive in chronic granulomatous infections including TB. A diagnosis of RA 
could be made only on follow-up. None of our patients had any evidence of HIV infection. The diagnostic criteria place emphasis on the presence of concomitant extraarticular active TB and complete response to ATT without sequelae. Two patients had evidence of hypersensitivity phenomena and this can add to the cumulative score in the proposed diagnostic criteria.

All of the patients presented a difficult diagnostic challenge. Over half $(n=3)$ of patients were active health care workers and there was a strong female preponderance (4/5). Our case series was also a relatively young cohort as $4 / 5$ patients were between the ages of 28 to 32 years. The majority (3/4) of patients with Poncet's disease had constitutional symptoms. This is similar to the observations by Malaviya et al. (10) who reported that Poncet's disease typically affects juveniles or young adults with a female preponderance and constitutional symptoms. However, the one patient with the final diagnosis of RA also had constitutional symptoms.

The presence of active tuberculosis was difficult to confirm in cases 1 and 5. Both were health care workers who were exposed to patients with open TB. Case 1 had a history of childhood tuberculosis, which was successfully treated. After exclusion of all other possibilities, due to a high index of clinical suspicion, a PET CT was performed. Case 5 could not be subjected to imaging studies, as she was pregnant. In view of prolonged fever, weight loss and erythema nodosum, a clinical diagnosis of extra pulmonary TB was hypothesized, and a therapeutic trial of ATT was commenced. Both patients responded well to treatment with complete resolution of symptoms without sequelae. Some patients can develop Poncet's arthritis while on ATT, as in case 3. This patient required a short course of steroids and NSAIDs to help him symptomatically over the period of acute inflammation. This phenomenon could represent a type of immune reconstitution syndrome and research is needed in this area. Subsequently the patient has responded well to ATT with no sequelae.
Our study of the case series shows the potential clinical utility of the Sharma and Pinto (7) diagnostic criteria by which all the patients with Poncet's disease had a definite diagnosis as per the criteria. Case 4 had sputum-positive TB who presented with lower limb symmetric oligoarthritis and rheumatoid factor positivity. The patient responded well to ATT. However, arthritis persisted, and the patient developed early articular deformities. Therefore, the diagnosis of possible Poncet's disease was revised and a diagnosis of seropositive rheumatoid arthritis presenting as oligoarthritis was entertained. It is reassuring that, by applying the Sharma and Pinto criteria, the patient was only considered to have possible Poncet's disease.

\section{CONCLUSIONS}

Our study illustrates the clinical utility of the proposed criteria to help inform the diagnosis of Poncet's disease in routine clinical practice. An important finding from our case series is that if patients do not satisfy the diagnostic criteria for definite Poncet's disease, then it is vital to keep patients under close clinical review and to reconsider the diagnosis frequently. Future research is indicated to understand the etiopathogenesis of Poncet's disease and to educate clinicians as to the importance of maintaining a high index of suspicion about this rare, yet potentially easily treatable disease.

Disclosures: the authors declare no conflict of interest.

\section{REFERENCES}

1. Bhargava AD, Malaviya AN, Kumar A. Tuberculous rheumatism (Poncet's disease): a case series. Indian J Tuberc. 1998; 45: 215-9.

2. Bloxham CA, Addy DP. Poncet's disease: parainfective tuberculous polyarthropathy. $\mathrm{Br}$ Med J. 1978; 1: 1590.

3. Sood R, Wali JP, Handa R. Poncet's disease in a north Indian hospital. Trop Doctor. 1999; 29: 33-6.

4. Iwata H, Kinoshita M, Sumiya M, et al. Emergence of erosive polyarthritis coincident with Mycobacterium kansasii pulmonary infection 
in a patient with systemic sclerosis-rheumatoid arthritis overlap syndrome. Clin Exp Rheumatol. 1999; 17: 757-8.

5. Rueda JC, Crepy MF, Mantilla RD. Clinical features of Poncet's disease. From the description of 198 cases found in the literature. Clin Rheumatol. 2013; 32: 929-35.

6. Tbfacts.org. TB Statistics India - National, treatment outcome, state. Available from: https://www.tbfacts.org/tb-statistics-india/

7. Sharma A, Pinto B, Dogra S, et al. A case series and review of Poncet's disease, and the utility of current diagnostic criteria. Int $\mathbf{J}$ Rheum Dis. 2016; 19: 1010-7.

8. Novaes GS, Kalil G, Borrelli FE. Criteria for diagnosis for Poncet's disease. Rev Bras Reumatol. 1992; 32: 20-6.

9. Kroot EJ, Hazes JM, Colin EM, Dolhain RJ. Poncet's disease: reactive arthritis accompanying tuberculosis. Two case reports and a review of the literature. Rheumatology. 2007; 46: 484-9.

10. Malaviya AN, Kotwal PP. Arthritis associated with tuberculosis. Best Prac Res Clin Rheumatol. 2003; 17: 319-43. 